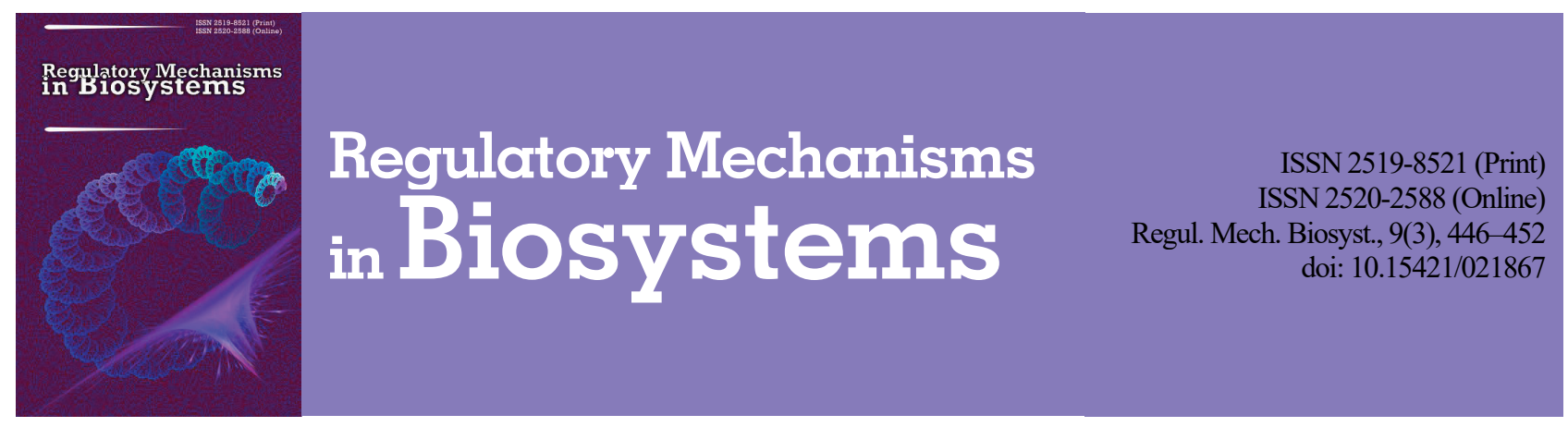

\title{
Cytogenetic anomalies of winter wheat cells, induced by chemical contamination of the territory of Kalush industrial district
}

\author{
V. V. Morgun, R. A. Yakymchuk \\ Institute of Plant Physiology and Genetics, NAS of Ukraine, Kyiv, Ukraine
}

Article info

Received 29.06.2018

Received in revised form 07.08 .2018

Accepted 13.08.2018

Institute of Plant

Physiology and Genetics,

NAS of Ukraine,

Vasylkivska st., 31/17,

Kyiv, 03022, Ukraine.

Tel.: +38-097-341-89-12.

E-mail:

peoplenature16@gmail.com

\begin{abstract}
Morgun, V. V., \& Yakymchuk, R. A. (2018). Cytogenetic anomalies of winter wheat cells, induced by chemical contamination of the territory of Kalush industrial district. Regulatory Mechanisms in Biosystems, 9(3), 446-452. doi:10.15421/021867
\end{abstract}

Mass accumulation of toxic waste near inhabited localities has changed some regions of Ukraine, in particular Kalush industrial area (Ivano-Frankivsk region), into zones of ecological disaster. Research on cytogenetic anomalies caused by chemical soil contamination of the territories of toxic chemical warehouses will be useful in determining the level of mutagenic activity of xenobiotics when they enter the environment and potential mechanisms of the induction of chromosome reconstructions by them and mitosis disorders. The aim of the research is to study frequency and spectrum of the types of cytogenetic disorders in T. aestivum L. under the prolonged effect on the seeds of soil contaminated with hexachlorinebenzene from territories of toxic waste warehousing and to determine the level of their mutagenic activity as compared with the effect of moderate and high concentrations of N-nitrozo-Nmethylurea (NMU). Seeds of winter wheat cultivars Al'batros odes'kyi and Zymoiarka were sprouted in the soil samples taken from the toxic waste ground of LLC "Oriana Halev", its recultivated area and the dump area of Dombrovskyi potash ore mine, situated near Kalush city. Hexachlorobenzene concentrations in the soil of the studied areas exceeded CPC by 1233-18350 times. Soil samples from a tentatively clean area of Svatky village, Hadiach district, Poltava region were taken as the control. To study cytogenetic consequences of the effect of moderate and high concentrations of NMU, wheat seeds were kept in a mutagen water solution at concentrations $0.005 \%, 0.010 \%, 0.025 \%$. Frequency and spectrum of cytogenetic anomalies were determined in the cells of sprout root meristem using the anatelophase technique. Chemical contamination of the soil exhibited high mutagenic activity which, by induction frequency of cytogenetic anomalies, exceeded the control level by 1.8-3.8 times and equalled mutagenic activity of NMU in moderate concentrations. The highest level of cytogenetic disorders, which exceeded spontaneous indicators by 3.4 3.8 times, was found when the soil contamination of the territory of the toxic waste ground with hexachlorobenzene was the most intensive. Traces of hexachlorobenzene in the soil of the recultivated plot of the ground continue to manifest high cytogenetic activity and pose a threat for the genomes of living organisms. Frequency of chromosome aberrations at a low hexachlorobenzene concentration in the soil of the disposal area of Dombrovskyi mine exceeded spontaneous indicators by 1.8-2.4 times, which is the result of its complex effect with natural-mineral compounds of mining-chemical raw materials. The increase of some bridges and acentric chromosome rings - markers of a radiation effect - among the types of cytogenetic disorders, induced by the soil contamination with hexachlorobenzene, confirms the radiometric properties of the xenobiotic, which were identified at high concentrations of NMU. The increase in the number of the cells with multiple aberrations, induced by the hexachlorobenzene contamination of the soil holding the studied objects proves the high genotoxicity of the chemical compound and the threat of serious genetic consequences if it enters the environment.

Keywords: Triticum aestivum L.; toxic waste; mitosis disorders; chromosome aberrations; mutagenic activity.

\section{Introduction}

Mutative changes of organisms are a required factor of evolution, they make the genome dynamic and flexible, help active response to environmental changes and are an adaptive feature of species (Lynch, 2016; Gervais \& Roze, 2017; La Croixetal., 2017). In the conditions of increasing techno-genic load in the form of physical and chemical mutagens, controlling systems of genomic reconstructions fail to ensure their stable spontaneous level. Induced genetic disorders are revealed by genome destabilization (Chan et al., 2014; Kumar \& Pandey, 2015), kinds of development (Aoki, 2017; Yahaya et al., 2017), the increase of genetic load in the populations, changes in the trends of natural selection (Sirohi et al., 2014; Henn et al., 2015), the decrease of lifespan (Chen et al., 2013; Correia et al., 2013), disorder of sexual dimorphism, individual death (Doorn, 2014; Kumar \& Pandey, 2015).

Based on the generalization of the research results concerning the factors of chemical pollution of the environment, it has been established that wastes of danger category, $1-3,8 \mathrm{mln} t$ of which are annually formed in Ukraine, show the highest genotoxicity. Their mass accumulation in the ground near inhabited localities have changed some regions of Ukraine, in particular Kalush city and adjacent villages Kropyvnyk and Sivka-Kaluska in Ivano-Frankivsk region, into zones of ecological disaster (Al-Naber et al., 2016). Intensive soil, water and air contamination of Kalush industrial district with highly toxic substances from the largest deposit of toxic waste in Europe - LLC "Oriana Halev" and Dombrovskyi potash ore mine, where 11,087.6 t of hexachlorobenzene are stored according to official data (about $50 \%$ of all the available waste of danger category I in the territory of Ukraine) (Lysychenko et al., 2015), have caused an increase in the level of genetic pathology, inborn anomalies, new formations, and somatic diseases of the main organ systems among local residents (Rozhko et al., 2014). Based on the estimation of the UN international experts, recultivation of the ground of the territory and removal of toxic waste for further utilization outside the country caused additional contamination of the region with highly toxic chemi- 
cal compounds and some concern of the world community as to a potential risk of trans-border ecological-technological disasters (Yakymchuk \& Valyuk, 2018).

Most research has focussed on monitoring and identifying the amount of xenobiotic concentration in the soil, water and foodstuffs (Parpan et al., 2016; Febbraio, 2017; Dent \& Dmytruk, 2017). The determination of the level of mutagenic danger to organisms of chemical soil contamination within areas of toxic waste warehousing is among the unsolved problems. To study their mutagenic activity and to define the mechanisms of occurrence of genetic disorder, it is important to research the effect of gene-toxicants on the functioning of a nucleus cell apparatus and frequency of cytogenetic disorders (Altwaty et al., 2016). The study of frequency and spectrum of cytogenetic anomalies, induced by chemical soil contaminants of the natural environment in comparison with the effect of different concentrations of the comprehensively-studied super-mutagens, among which are N-nitrozo-N-methylurea (NMU), is of great practical significance, and will make it possible to identify the level of mutagenic activity of the discovered xenobiotics and possible mechanisms of their induction of chromosome reconstructions and mitosis disorders.

When the effect of environmental harmful factors on the genetic apparatus of living organisms, including man, is studied, in most cases plant test-objects are used, as they facilitate the identification of various mutation types, they do not require serious financial expenses, and the experiments using them can be conducted in a shorter time (Firbas \& Amon, 2014; Babatunde \& Anabuike, 2015; Kumar \& Srivastava, 2015). The aim of the research is to study frequency and spectrum of the types of cytogenetic disorders in Triticum aestivum L. under the prolonged effect on the seeds of the soil contaminated with hexachlorobenzene in the territories of toxic waste warehousing and to determine the level of their mutagenic activity as compared with the effect of moderate and high concentrations of N-nitrozo-N-methylurea.

\section{Materials and methods}

Cytogenetic activity of soil chemical contamination in the territory of the toxic waste ground of LLC "Oriana Halev" and Dombrovskyi potash ore mine (Kalush city, Ivano-Frankivsk rgn.) was studied on winter wheat sprouts of cv. Al'batros odes'kyi and Zymoiarka with help of anatelophase method. Seeds were sprouted at $25^{\circ} \mathrm{C}$ in soil samples moistened with distilled water and taken by standard technique (Bekker \& Agaev, 1989) from the area within the toxic waste ground $\left(49^{\circ} 04^{\prime} \mathrm{N}\right.$, $\left.24^{\circ} 19^{\prime} \mathrm{E}\right)$, its recultivated area $\left(49^{\circ} 05^{\prime} \mathrm{N}, 24^{\circ} 19^{\prime} \mathrm{E}\right)$ and dump of Dombrovskyi mine ( $\left.49^{\circ} 01^{\prime} \mathrm{N}, 24^{\circ} 20^{\prime} \mathrm{E}\right)$ (Fig. 1). Hexachlorobenzene concentrations in the soil were $550.5,292.0$ and $37.0 \mathrm{mg} / \mathrm{kg}$, respectively, and exceeded CPC by $1233-18350$ times $(0.03 \mathrm{mg} / \mathrm{kg})$. Soil samples from a provisionally clean area of Svatky village, Hadiach district, Poltava region were taken as the control.

To study cytogenetic consequences of the effect of moderate and high concentrations of N-nitrozo-N-methylurea (NMU), wheat seeds were kept for 18 hours in water solution at concentrations $0.005 \%$, $0.010 \%, 0.025 \%$, after which they were placed in Petri dishes on filtered paper, moistened with distilled water. Seeds moistened in distilled water were taken as the control.

Primary rootlets, $0.8-1.0 \mathrm{~cm}$ long, were fixed during 4 hours in Clark holder. Their chemical maceration was done during 1 minute in $1 \mathrm{n}$ solution of hydrochloric acid. When maceration was over, the rootlets were exposed to $23-25^{\circ} \mathrm{C}$ for 24 hours in aceto-orcein solution. Temporary crushed cytological preparations were used for microscopic analysis according to standard technique (Pausheva, 1988). Microscopic study of root meristem cells was carried out using the microscope Jenaval (Carl Zeiss Jena) at magnification $600^{x}$. When identifying frequency of chromosome aberrations and mitosis disorders, cells which were in anaphase and early telophase were examined. Microphotography was done with help of Olympus SP-500 UZ integrated into a microscope at microscope magnification $900^{\mathrm{x}}$ and software Quick Photo Micro 2.3 for Windows (Olympus). Sampling for each variant used at least 1000 cells, which were analyzed in 20 and more primary rootlets. Frequency of aberrant cells was considered as a percentage of cells in anaphase and early telophase which had chromosome disorders. When average number of aberrations per aberrant cell was calculated, cells with $0,1,2$ and multiple chromosome aberrations ( $>2$ aberrations) were taken into account. Statistical processing of experimental data was done by standard technique. Percentage shares of chromosome aberrations and average errors of sampled arithmetic averages are given in the tables.

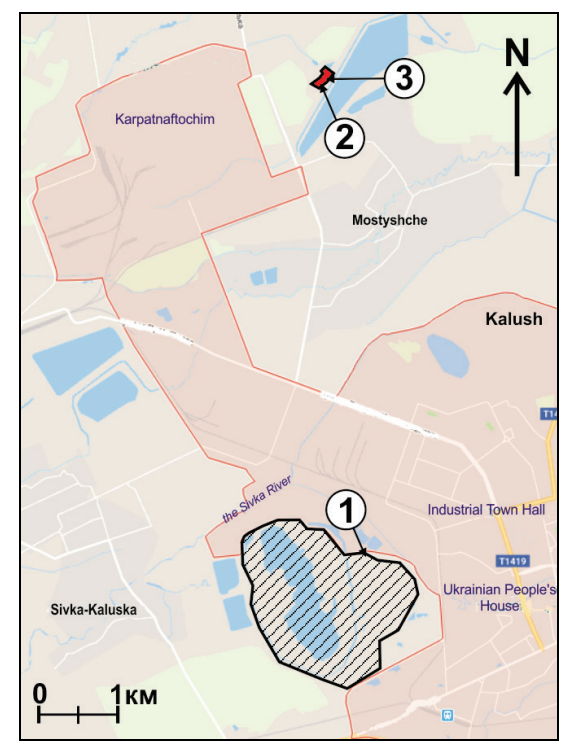

Fig. 1. Soil sampling areas near Kalush city, Ivano-Frankivsk rgn.: 1 -dumps of Dombrovskyi mine, 2 - toxic waste ground of LLC "Oriana Halev", 3 - recultivated area of the toxic waste ground of LLC "Oriana Halev"

\section{Results}

The prolonged effect of chemical factors of soil contamination from the territory of the toxic waste ground of LLC "Oriana Halev" and Dombrovskyi potash ore mine in Kalush city on wheat seeds caused the frequency increase of chromosome aberrations in primary rootlets of winter wheat, which was $1.51-2.35 \%$ for cultivar Al'batros odes'kyi and $1.37-2.51 \%$ for cultivar Zymoiarka, and it exceeded the control level by $1.8-3.8$ times (Table 1). Its highest indicators $-2.35 \%$ for Al'batros odes'kyi and $2.51 \%$ for Zymoiarka - were recorded on the most intensively hexachlorobenzene contaminated soil area of the toxic waste ground. Frequency of cytogenetic disorders exceeded the control level by 3.4-3.8 times. The concentration of residual amount of hexachlorobenzene in the soil of a recultivated plot of the ground decreased twice, as compared with a previous variant. However, chemical contamination continued to maintain high mutagenic activity, which was confirmed by a statistically reliable induced increase in the number of aberrant cells of root meristem by 2.6-3.0 times. The frequency decrease of cytogenetic disorders regardless of the genotype of a winter wheat cultivar only by 1.3 times in the conditions of a doubled decrease of mutagen concentration proves that there is no direct correlation between the intensity of hexachlorobenzene soil contamination and the level of cytogenetic anomalies.

The level of cytogenetic disorders, induced by soil contamination near the dump of Dombrovskyi potash ore mine, exceeded control indicators by 1.8-2.4 times. The soils of Dombrovskyi mine dump contain bare-lying rocks, which include halite, kainite, langbanite, sylvite, kieserite, polyhalite, anhydrite, shungite, leonite and compounds $\mathrm{Ni}, \mathrm{Fe}$, $\mathrm{Mn}, \mathrm{Pb}, \mathrm{Cr}, \mathrm{Me}$, the concentrations of which exceed standard admissible rates considerably (Haidin et al., 2014). Besides, within the dump area of the mine, unsanctioned storage of thousands of tons of especially dangerous chemical substances - hexachlorobenzene and amines - took place, and they, being improperly isolated, enter the superficial soil layers. Hence, the preservation of high frequency of chromosome aberrations with further intensity decrease of soil hexachlorobenzene contamination by 8 times is classified as the result of the cumulative and synergetic effect of a complex impact of low concentrations of xenobiotics with natural mineral compounds of mining-chemical raw materials. 
When the water solution of NMU was at the lowest concentration $0.005 \%$, the level of induced cytogenetic disorders in the cells of root meristem increased by $3.5-10$ times: it was $2.74 \%$ for cultivar Al'batros odes'kyi and $5.82 \%$ for cultivar Zymoiarka, control indicators were $0.78 \%$ and $0.58 \%$, respectively (Table 2 ). Further doubling of NMU concentration $(0.01 \%)$ caused the increase of chromosome reconstructtion level in sprout cells of cultivars Al'batros odes'kyi and Zymoiarka of up to $3.92 \%$ and $7.13 \%$, respectively, which exceeded the control level by $5.0-12.3$ times. However, no statistically reliable difference between the indicators of aberrant cell frequency, induced by NMU in concentrations $0.005 \%$ and $0.010 \%$, was recorded. Further increase of NMU concentration by 2.5 times $(0.025 \%)$ was followed by the induction of the highest level of cytogenetic disorders in meristem cells of primary rootlets $-19.0 \%$ for cultivar Al'batros odes'kyi and $23.1 \%$ for cultivar Zymoiarka, which exceeded the control level by 24.4-39.7 times. A considerable increase of the number of cells with chromosome reconstructions shows a radiomimetic effect of the chemical mutagen impact in a high concentration.

The spectrum of the types of cytogenetic anomalies in winter wheat cells under the effect of contamination of the soil and NMU water solutions from the studied areas with hexachlorobenzene, except for acentric fragments and bridges, which were typical for the control variant, contained micronuclei, ring and lagging chromosomes (Fig. 2a, $b$ ). The correlation between frequency of induction of several types of chromosome aberrations and the genotype of the plants and the concentration of the active substance was recorded. The increase in frequency of chromosome aberrations in the cells of sprout root meristem under the effect of contamination of soil with hexachlorobenzene in the highest concentration (the territory of the toxic waste ground) is due to the induction of single acentric fragments $(1.18 \%$ ) in cultivar Al'batros odes'kyi and that of chromatide and chromosome bridges (1.07\%) in cultivar Zymoiarka (Table 3). As a result of the effect of contamination of soil with hexachlorobenzene in lower concentrations on wheat root meristem, which is typical for a recultivated plot of the toxic waste ground, frequency of the cells with acentric fragments remained at the level of a previous variant and was $0.88 \%$ for Al'batros odes'kyi and $0.90 \%$ for Zymoiarka (Fig. 3). But the share of bridges in total frequency of cytogenetic disorders decreased to the indicators of the control level. The increase of the number of clastogenic disorders in meristem cells of primary rootlets of wheat sprouts under soil chemical contamination near Dombrovskyi mine resulted from the formation of mainly acentric fragments in Al'batros odes'kyi and dicentric chromosomes in Zymoiarka.

\section{Table 1}

Frequency of anatelophase aberrations in winter wheat, induced by toxic waste contamination of soil $(x \pm S E)$

\begin{tabular}{|c|c|c|c|c|c|c|}
\hline \multirow{3}{*}{ Soil sampling area } & \multirow{2}{*}{$\begin{array}{c}\text { Studied } \\
\text { anatelo- } \\
\text { phase } \\
\text { mitoses, } \\
\text { pcs } \\
\end{array}$} & \multicolumn{2}{|c|}{$\begin{array}{l}\text { Mitoses with } \\
\text { cytogenetic } \\
\text { disorders }\end{array}$} & \multirow{2}{*}{$\begin{array}{c}\text { Studied } \\
\text { anatelop } \\
\text { hase } \\
\text { mitoses, } \\
\text { pcs }\end{array}$} & \multicolumn{2}{|c|}{$\begin{array}{l}\text { Mitoses with } \\
\text { cytogenetic } \\
\text { disorders }\end{array}$} \\
\hline & & pcs & $\%$ & & pes & $\%$ \\
\hline & \multicolumn{3}{|c|}{ Al'batros odes'kyi } & \multicolumn{3}{|c|}{ Zymoiarka } \\
\hline $\begin{array}{l}\text { Svatky village, Poltava } \\
\text { rgn. (control) }\end{array}$ & 1291 & 8 & $0.62 \pm 0.22$ & 1200 & 9 & $0.75 \pm 0.25$ \\
\hline $\begin{array}{l}\text { Toxic waste ground of } \\
\text { LLC "Oriana Halev" }\end{array}$ & 1107 & 26 & $2.35 \pm 0.46^{* *}$ & 1592 & 40 & $2.51 \pm 0.39^{* *}$ \\
\hline $\begin{array}{l}\text { Recultivated area of the } \\
\text { toxic waste ground of } \\
\text { LLC "Oriana Halev" }\end{array}$ & 1133 & 21 & $1.85 \pm 0.40^{*}$ & 1219 & 24 & $1.97 \pm 0.40^{*}$ \\
\hline $\begin{array}{l}\text { Dombrovskyi potash } \\
\text { ore mine }\end{array}$ & 1126 & 17 & $1.51 \pm 0.36^{*}$ & 1166 & 16 & $1.37 \pm 0.34$ \\
\hline
\end{tabular}

Notes: ${ }^{*}$ - difference as to the control is statistically reliable at $\mathrm{P}<0.05$, ${ }^{* *}$ - at $\mathrm{P}<0.01$.

\section{Table 2}

Frequency of anatelophase aberrations in winter wheat, induced by NMU

\begin{tabular}{|c|c|c|c|c|c|c|}
\hline \multirow{3}{*}{$\begin{array}{l}\text { Mutagen } \\
\text { concentration }\end{array}$} & \multirow{2}{*}{$\begin{array}{c}\text { Studied } \\
\text { anatelopha- } \\
\text { se mitoses, } \\
\text { pcs }\end{array}$} & \multicolumn{2}{|c|}{$\begin{array}{l}\text { Mitoses with cytoge- } \\
\text { netic disorders }\end{array}$} & \multirow{2}{*}{$\begin{array}{c}\text { Studied } \\
\text { anatelopha- } \\
\text { se mitoses, } \\
\text { pcs }\end{array}$} & \multicolumn{2}{|c|}{$\begin{array}{l}\text { Mitoses with cyto- } \\
\text { genetic disorders }\end{array}$} \\
\hline & & pcs & $\%$ & & pcs & $\%$ \\
\hline & \multicolumn{3}{|c|}{ Al'batros odes'kyi } & \multicolumn{3}{|c|}{ Zymoiarka } \\
\hline & 09 & 7 & 078 & 1210 & & \\
\hline NML & 39 & 34 & 2.74 & 1117 & 65 & 5.82 \\
\hline NML & 1122 & 44 & $3.92 \pm 0.60^{*}$ & 1319 & 94 & $7.13 \pm 0.71^{*}$ \\
\hline NMU, $0.025 \%$ & 1067 & 203 & $19.03 \pm 1.20^{* \#}$ & 976 & 225 & $3.05 \pm 1.35$ \\
\hline
\end{tabular}

Notes: ${ }^{*}$ - difference as to the control is statistically reliable at $\mathrm{P}<0.01$; ${ }^{\#}$ difference as to variant NMU $0.005 \%$ and NMU $0.010 \%$ is statistically reliable at $\mathrm{P}<0.01$

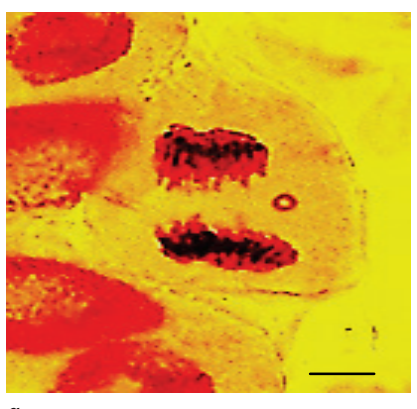

$a$

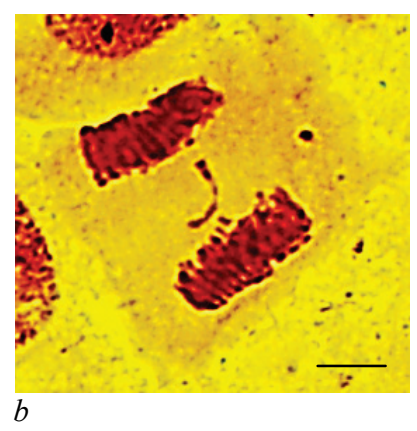

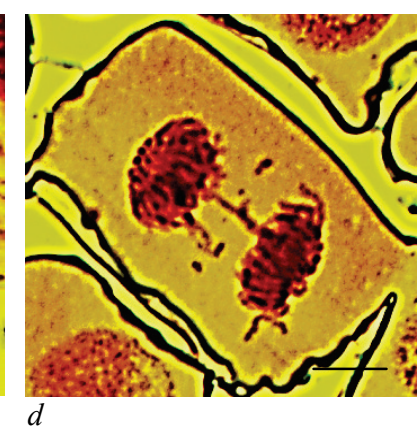

Fig. 2. Chromosome aberrations and mitosis disorders in root meristem of winter wheat, induced by toxic waste contamination of soil: $a$-ring chromosome, $b$ - lagging chromosome, $c$ - pair acentric fragments and lagging chromosome, $d$ - multiaberrations; bar - $5 \mu \mathrm{m}$

The frequency variation of fragments and bridges depending on the genotype of the plants and the concentration of mutagen was also recorded under the effect of NMU on winter wheat (Table 4). The effect of the supermutagen in concentration $0.005 \%$ caused a serious increase of both acentric fragments and chromatide bridges in mitotic cells of root meristem of wheat sprouts of cultivar Zymoiarka (2.78\% and $0.89 \%$, respectively, the control level was $0.33 \%$ and $0.25 \%$ ), whereas in the cells of root meristem of cultivar Al'batros odes'kyi only frequency of acentric fragments increased $(1.69 \%$, the control level was $0.43 \%$ ) (Fig. 4). The increase of NMU concentration to $0.01 \%$ was followed by a considerable increase of fragment and bridge frequency in the cells of root meristem of cultivar Zymoiarka, but a decrease of the number of cells with acentric fragments $(0.89 \%)$ and increase in cells with dicentrics (1.25\%) was seen in cultivar Al'batros odes'kyi. A serious increase in acentric fragments (8.34-9.02\%) was recorded under the effect of NMU in high concentrations $(0.025 \%)$ for both cultivars; most of them were pair ones. The frequency indicator of anatelophase cells with chromatide bridges, as compared with the previous variant of mutagen effect, did not change significantly.

Thus, the appearance of a great number of cells with dicentrics in wheat root meristem, induced by hexachlorobenzene contamination of the soil near the toxic waste ground, confirms the radiomimetic properties of the chemical compound. According to the results of studying cytogenetic consequences of NMU impact, the abovementioned type of chromosome aberrations with high frequency may occur under moderate and high concentrations of mutagen.

Contamination of the soil of the studied territories with hexachlorobenzene caused the appearance of the cells with ring chromosomes, which may point to the lack of affinity of chemical mutagens with genetic cell structures and the mechanism of their effect by a principle of a 
target - accidentally. The spectrum of the types of cytogenetic disorders, as NMU concentration increased, extended with the appearance of ring chromosomes. They are markers of radiation effect (Ryu et al., 2016; Marković et al., 2017), which is why the appearance of such chromosome aberrations, affected by NMU in concentration $0.025 \%$ and hexachlorobenzene contamination of the soil in the areas of its storage with frequency $0.19-0.51 \%$ and $0.06-0.19 \%$ respectively, confirm radiomimetic properties of the studied xenobiotics.

Table 3

Spectrum of types of anatelophase chromosome aberrations in winter wheat, induced by toxic waste contamination of soil ( $x \pm \mathrm{SE})$

\begin{tabular}{|c|c|c|c|c|c|c|c|}
\hline \multirow[b]{2}{*}{ Soil sampling area } & \multicolumn{6}{|c|}{ Frequency of types of mitosis disorders and chromosome aberrations, $\%$} & \multirow[b]{2}{*}{$\begin{array}{l}\text { Number of aberra- } \\
\text { tions per aberrant cell }\end{array}$} \\
\hline & fragments & bridges & $\begin{array}{l}\text { fragments } \\
\text { and bridges }\end{array}$ & micronuclei & $\begin{array}{c}\text { lagging } \\
\text { chromosomes }\end{array}$ & $\begin{array}{l}\text { chromosome } \\
\text { rings }\end{array}$ & \\
\hline \multicolumn{8}{|c|}{ Al'batros odes'kyi } \\
\hline Svatky village, Poltava rgn. (control) & $0.08 \pm 0.08$ & $0.54 \pm 0.20$ & 0 & 0 & 0 & 0 & 1.00 \\
\hline Toxic waste ground of LLC "Oriana Halev" & $1.18 \pm 0.32 *$ & $0.99 \pm 0.30$ & 0 & $0.09 \pm 0.09$ & 0 & $0.09 \pm 0.09$ & $1.19^{*}$ \\
\hline $\begin{array}{l}\text { Recultivated area of the toxic waste ground } \\
\text { of LLC "Oriana Halev" }\end{array}$ & $0.88 \pm 0.28 *$ & $0.53 \pm 0.21$ & 0 & 0 & $0.26 \pm 0.15$ & $0.18 \pm 0.12$ & 1.05 \\
\hline Dombrovskyi potash ore mine & $0.53 \pm 0.21$ & $0.62 \pm 0.23$ & 0 & 0 & $0.36 \pm 0.18^{*}$ & 0 & $1.18^{*}$ \\
\hline \multicolumn{8}{|c|}{ Zymoiarka } \\
\hline Svatky village, Poltava rgn. (control) & $0.42 \pm 0.18$ & $0.33 \pm 0.16$ & 0 & 0 & 0 & 0 & 1.00 \\
\hline Toxic waste ground of LLC “Oriana Halev" & $0.88 \pm 0.23$ & $1.07 \pm 0.26^{*}$ & $0.12 \pm 0.08$ & 0 & $0.38 \pm 0.15^{*}$ & $0.06 \pm 0.06$ & $1.45^{* *}$ \\
\hline $\begin{array}{l}\text { Recultivated area of the toxic waste ground } \\
\text { of LLC "Oriana Halev" }\end{array}$ & $0.90 \pm 0.27$ & $0.66 \pm 0.23$ & $0.08 \pm 0.08$ & 0 & $0.25 \pm 0.14$ & $0.08 \pm 0.08$ & $1.38 * *$ \\
\hline Dombrovskyi potash ore mine & $0.43 \pm 0.19$ & $0.69 \pm 0.24$ & 0 & $0.09 \pm 0.09$ & $0.09 \pm 0.09$ & $0.09 \pm 0.09$ & 1.19 \\
\hline
\end{tabular}

Notes: *-difference as to the control is statistically reliable at $\mathrm{P}<0.05$, ** - at $\mathrm{P}<0.01$.
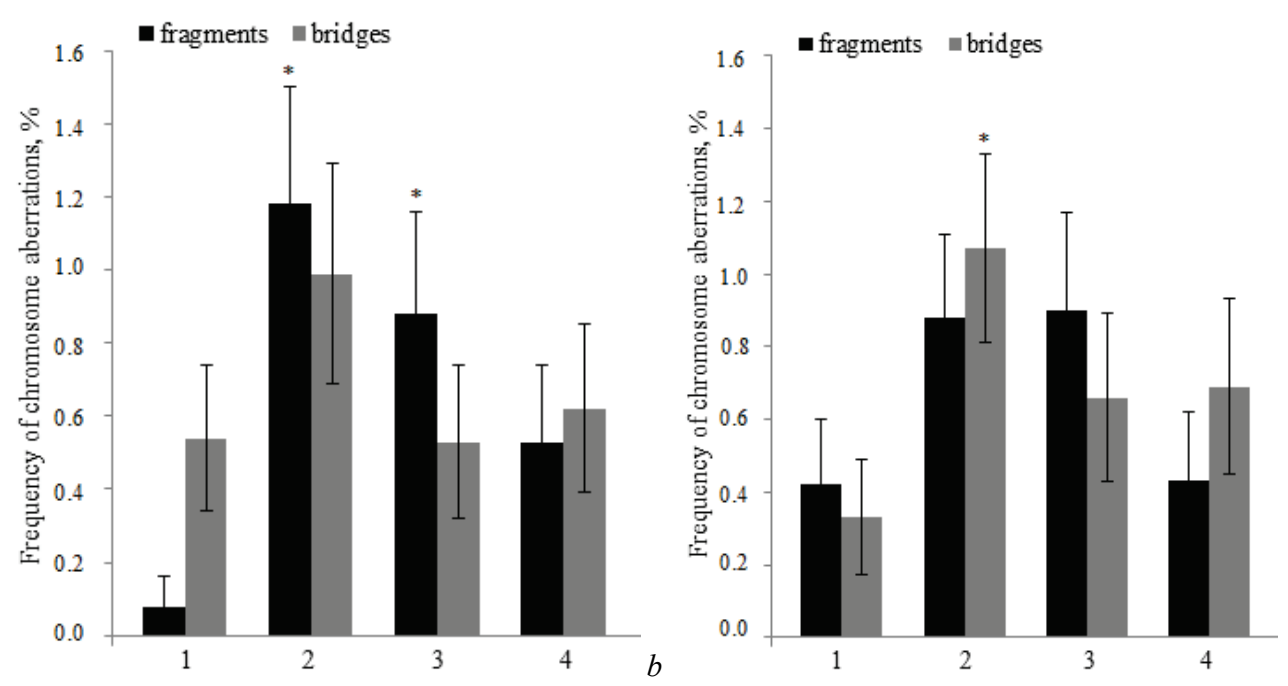

Fig. 3. Induction of acentric fragments and bridges by toxic waste contamination of soil in the cells of root meristem of winter wheat, cultivars Al'batros odes'kyi (a) and Zymoiarka (b): 1 - Svatky village, Poltava rgn. (control), 2 - toxic waste ground of LLC "Oriana Halev", 3 - recultivated area of the toxic waste ground of LLC "Oriana Halev", 4 - Dombrovskyi potash ore mine; $*_{-} \mathrm{P}<0.05$ compared to the control; $\mathrm{n}=1000, \mathrm{x} \pm \mathrm{SE}$

Chemical soil contaminants in the territory of the toxic waste ground and Dombrovskyi mine show the ability to cause aneuploid cells at frequency $0.09-0.38 \%$. A statistically reliable increase of the level of lagging chromosomes caused by chemical contamination of the soil of the toxic waste ground and the dump of Dombrovskyi mine was $0.38 \%$ for cultivar Zymoiarka and $0.36 \%$ for cultivar Al'batros odes'kyi, respectively. Analysis of frequency of aneugenic effects under the impact of NMU in concentration $0.005 \%$ and $0.010 \%$ established that the level of the cells with lagging chromosomes is in direct correlation with the concentration of supermutagen. Frequency of the formation of the cells with lagging chromosomes in sprout root meristem of cultivars Al'batros odes'kyi and Zymoiarka was $0.65-1.33 \%$ and $1.70-2.12 \%$, respecttively. A considerable increase in cytogenetic disorder frequency due to the induction of the cells with lagging chromosomes was observed at high concentration of chemical mutagen $(0.025 \%)$, which was $8.34 \%$ for cultivar Al'batros odes'kyi and $11.47 \%$ for cultivar Zymoiarka.

Cells with more than two chromosome reconstructions were found among the aberrant cells, induced by soil contamination with chemical mutagens. The highest number of indicators of aberrations per aberrant cell, which were equal to the indicators, found at moderate and high concentrations of NMU, was characteristic of the cells of primary rootlet meristem of winter wheat sprouts of cultivar Zymoiarka, which were affected by contamination of the soil of the toxic waste ground
(1.45) and its recultivated area (1.38) with hexachlorobenzene. Complex cytogenetic disorders in meristem cells of cultivar Al'batros odes'kyi were formed with lower frequency, however, under the effect of hexachlorobenzene in the highest and lowest concentrations, which is typical for soil contamination near the toxic waste ground and dumps of Dombrovskyi potash ore mine, the indicator of aberration number per aberrant cell reliably exceeded the control level. The majority of cytogenetic anomalies in the cells with multiple aberrations were presented with acentric fragments and lagging chromosomes. Also cells were found which included three acentric fragments at the same time, two lagging chromosomes, a single acentric fragment and a bridge, pair acentric fragments and a bridge, pair acentric fragments and a lagging chromosome (Fig. $2 c, d$ ). Heavy cytogenetic disorders, induced by low hexachlorobenzene concentrations in the soil, can be associated with a cumulative or synergetic effect of their combined impact with chemical factors of natural origin.

\section{Discussion}

Based on the results of numerous trials it has been established that chemical mutagens increase natural plant variability by tens of thousands times, cause a great variation of inherited changed forms. The advantage of chemical compounds in low and moderate concentrations, as compared with radiation, is high induction frequency of point mutations 
and a low level of chromosome reconstructions (Venken \& Bellen, 2014; Oladosu et al., 2016). But chemical mutagens in high concentrations produce an opposite effect, mostly inducing damage of the nuclear cell apparatus in the form of chromosome and aneuploid reconstructions, which corresponds to a severe effect of ionizing radiation. Although some believe that frequency of gene mutations increases along with the increase of the concentration of chemical mutagen factors, their identi- fycation in a phenotype is hindered by chromosome aberrations, mitosis anomalies, abiosis (Jejges, 2013). Taking into account the specificity of effect of mechanisms of chemical mutagens, connected with the correspondence of dipole moments of their molecules with dipole moments of certain molecular cell structures - preceding ones of DNA and protein synthesis, a predominant type of genetic material disorders is mutations of some chromosome loci (Bulathsinghala \& Shaw, 2014).

Table 4

Spectrum of types of anatelophase chromosome aberrations in winter wheat, induced by NMU $(x \pm S E)$

\begin{tabular}{|c|c|c|c|c|c|c|c|}
\hline \multirow[b]{2}{*}{$\begin{array}{c}\text { Mutagen } \\
\text { concentration }\end{array}$} & \multicolumn{6}{|c|}{ Frequency of types of mitosis disorders and chromosome aberrations, $\%$} & \multirow{2}{*}{$\begin{array}{c}\text { Number of } \\
\text { aberrations per } \\
\text { aberrant cell }\end{array}$} \\
\hline & fragments & bridges & $\begin{array}{c}\text { fragments and } \\
\text { bridges }\end{array}$ & micronuclei & $\begin{array}{c}\text { lagging } \\
\text { chromosomes }\end{array}$ & chromosome rings & \\
\hline \multicolumn{8}{|c|}{ Al'batros odes'kyi } \\
\hline Water (control) & $0.43 \pm 0.17$ & $0.57 \pm 0.20$ & 0 & 0 & $0.07 \pm 0.07$ & 0 & 1.09 \\
\hline NMU, $0.005 \%$ & $1.69 \pm 0.36^{* *}$ & $0.40 \pm 0.18$ & 0 & 0 & $0.65 \pm 0.23^{*}$ & 0 & 1.21 \\
\hline NMU, $0.010 \%$ & $0.89 \pm 0.28$ & $1.25 \pm 0.33$ & $0.18 \pm 0.12$ & $0.09 \pm 0.09$ & $1.33 \pm 0.34 * *$ & $0.18 \pm 0.12$ & 1.14 \\
\hline NMU, $0.025 \%$ & $8.34 \pm 0.84 * *$ & $1.31 \pm 0.35$ & $0.66 \pm 0.25 *$ & $0.19 \pm 0.13$ & $8.34 \pm 0.84 * *$ & $0.19 \pm 0.13$ & $1.52 * *$ \\
\hline \multicolumn{8}{|c|}{ Zymoiarka } \\
\hline Water (control) & $0.33 \pm 0.16$ & $0.25 \pm 0.14$ & 0 & 0 & 0 & 0 & 1.14 \\
\hline NMU, $0.005 \%$ & $2.78 \pm 0.49^{* *}$ & $0.89 \pm 0.28 *$ & $0.09 \pm 0.09$ & $0.36 \pm 0.18$ & $1.70 \pm 0.39 * *$ & 0 & 1.47 \\
\hline NMU, $0.010 \%$ & $3.18 \pm 0.48 * *$ & $1.37 \pm 0.32 * *$ & $0.15 \pm 0.11$ & $0.23 \pm 0.13$ & $2.12 \pm 0.40^{* *}$ & $0.08 \pm 0.08$ & 1.40 \\
\hline NMU, $0.025 \%$ & $9.02 \pm 0.92^{* *}$ & $1.33 \pm 0.36^{* *}$ & 0 & $0.72 \pm 0.27^{* *}$ & $11.47 \pm 1.02 * *$ & $0.51 \pm 0.23^{*}$ & $1.48^{*}$ \\
\hline
\end{tabular}

Notes: ${ }^{-}$- difference as to the control is statistically reliable at $\mathrm{P}<0.05,{ }^{*}{ }_{-}$at $\mathrm{P}<0.01$.

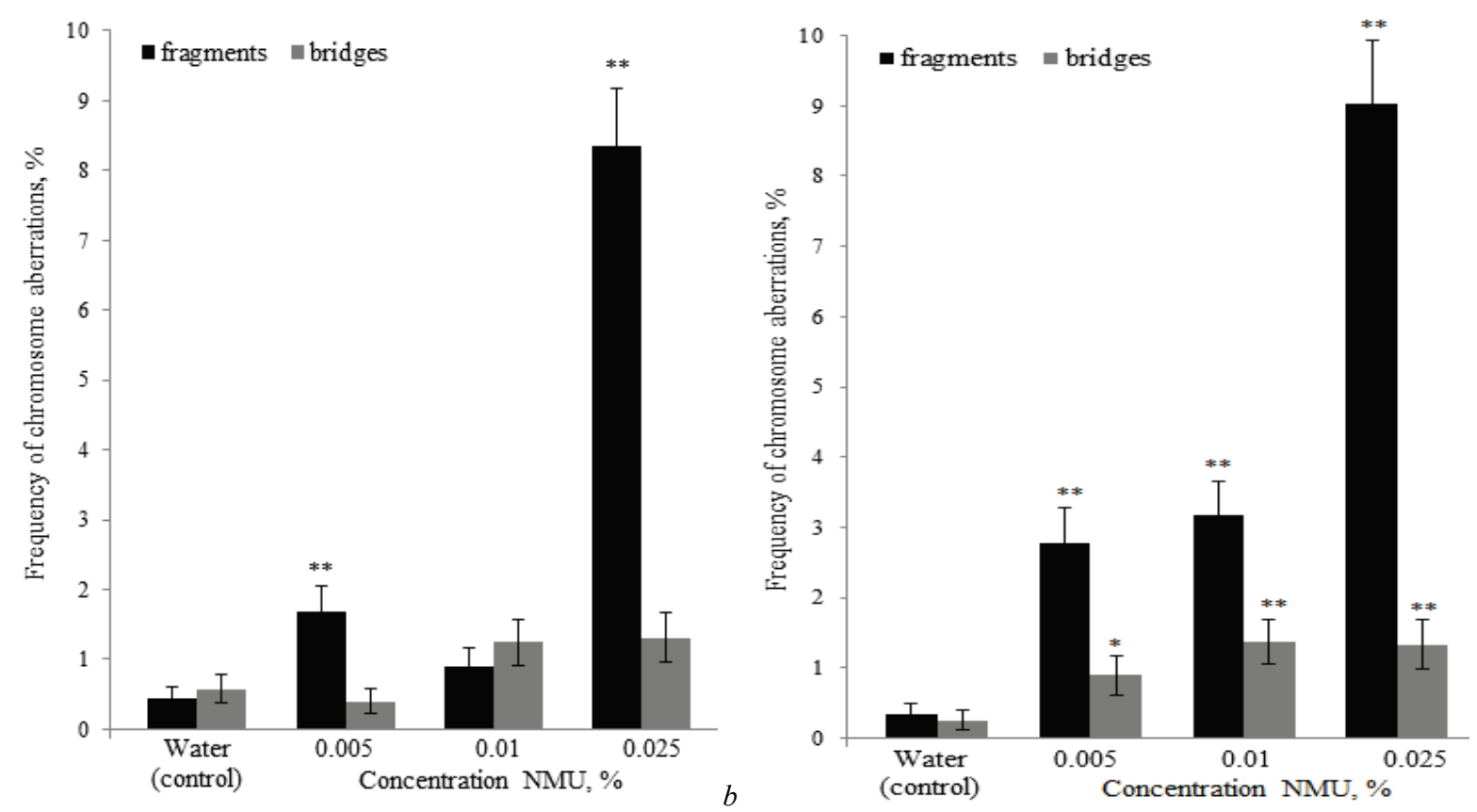

Fig. 4. Induction of acentric fragments and bridges under the effect of $\mathrm{N}$-nitrozo-N-methylurea in the cells of root meristem of winter wheat, cultivars Al'batros odes'kyi $(a)$ and Zymoiarka $(b): *-\mathrm{P}<0.05$ compared to the control, ** $-\mathrm{P}<0.01 ; \mathrm{n}=1000, \mathrm{x} \pm \mathrm{SE}$

This point of view was grounded on the results of study of mutagenic activity of alkylating compounds in low and moderate concentrations. It is under these conditions that one can expect the induction of high frequency of point mutations and a low level of chromosome aberrations, which gives preferences to extended and efficient usage of chemical mutagens in breeding practice. Chemical mutagens in high concentrations produce a more occasional effect; they induce serious damage to genetic cell apparatus and the appearance of numerous cytogenetic disorders. Which is why one can assume that the lack of a serious difference between frequency of cells with chromosome aberrations under the effect of NMU in concentrations $0.005 \%$ and $0.010 \%$ and the effect of hexachlorobenzene contamination of soil near the toxic waste ground and its recultivated area is connected with the increase of specific genetic disorders at higher mutagen concentrations of point mutations, which are not identified with help of cytogenetic analysis and require research on mutative plant variability at the level of phenotype and molecular-genetic inherited changes. A non-linear dependence of genetic disorders on the concentration of chemical mutagens is also associated with the varied efficiency of reparation processes and different ways of their biotransformation (Budinsky et al., 2013). NMU is considered to make its main contribution to mutagenic effect as a result of the response of the interaction of decay products with biopolymers and, as one of the consequences, blocking the threads of spindle separation rather than through a direct mutagen attack of DNA molecules (Usatov et al., 2005). Chemical mutagen in high concentrations directly affects chromosome heterochromatin in the area of the centromere which causes chromosome lagging in a mitosis anatelophase (Jejges, 2013). Considering the insufficient study of the mechanisms of chemical interaction of hexachlorobenzene with inherited cell structures, one can assume that its high mutagenic activity is explained by the formation of a set of highly toxic compounds resulting from mutagen metabolism in a plant cell.

The high frequency of cytogenetic anomalies which was recorded when wheat seeds were sprouted in the dump soil of Dombrovskyi potash ore mine can be explained by the effect of synergetic interaction between low concentrations of hexachlorobenzene residues and a complex of heavy metals and natural mineral compounds of mining-chemical 
raw materials. Synergetic responses of biological systems are observed when factors different in their nature act together: gamma-rays and chemical mutagens, heavy metals and radio nuclides, heavy metals and hypothermia, chemical mutagens and ultra-violet rays, laser radiation and magnetic field, etc. (Ang et al., 2016; Song et al., 2016; Kayalvizhi et al., 2017). The existence of a synergetic effect, under the impact of chemical environmental factors, which are particularly seen in small concentrations, was proved on lentils (Lens culinaris Medik.) (Laskar \& Khan, 2017), winter cherry (Physalis peruviana L.) (Gupta et al., 2018), nematodes (Caenorhabditis elegans) (Guo et al., 2014), human cells (Devid et al., 2016). It has been established that synergetic effects are seen more often in a range of low dose loads than in the case of strong impacts. The processes of a direct mutagenic effect become of great importance when concentrations are high.

As a rule, the induction with high frequency of bridges, in particular chromosome ones, is a typical cytogenetic consequence of the effect of ionizing radiations (M'kacher et al., 2015; Syaifudin et al., 2017). The formation of a great number of cells with dicentrics in wheat root meristem, induced by the effect of hexachlorobenzene contamination of soil in the area of the toxic waste ground near Kalush city, confirms the radiomimetic properties of the chemical compound, which, based on the results of the research aimed at studying mutagenic NMU activity, can be seen under the impact of high mutagen concentrations. When seeds were sprouted in the samples of the studied soil objects, contaminated with chemical factors, single cases of ring chromosomes were observed - indicators of radiation impact, which prove the lack of the relationship of chemical mutagens with genetic cell structures and the mechanism of their effect by a principle of a target - accidentally (Oladosua et al., 2016). Their formation can be explained by the loss of telomere fragments, which leads to the loss of the connection of chromosomes with the nucleus wall and destruction of the architectonics of the nucleus (Zuccarello et al., 2010; Guilherme et al., 2011).

The effect of chemical mutagens is considered to lead to gene mutations or damages of mitotic spindle (Mohapatra et al., 2014). A serious increase in frequency of chromosome segregation disorders, which is found under the effect of hexachlorobenzene contamination of the soil of the toxic waste ground and Dombrovskyi mine, can be a consequence of the interaction of mutagen not only with microtube protein of spindle separation, but also with heterochromatin of nearby-centromere areas of chromosomes. A chemical mutagen in high concentrations directly affects chromosome heterochromatin in the area of the centromere which causes chromosome lagging into a mitosis or meiosis anatelophase (Jejges, 2013). It is with this mechanism of the appearance of cytogenetic disorders that a considerable increase in the number of aneuploid cells, under the effect of NMU in a high concentration, is connected.

Some authors connect the induction of multiple aberrations in the cells of wheat root meristem with chemical factors, which include a complex of chromosome reconstructions or chromosome reconstructions and mitosis anomaly, with many-sided chemical interaction of mutagens and biopolymeric nucleus structures. In particular, it has been shown for plant objects that the wide spectrum of NMU effect is caused not only by alkylating, but also by nitrating and carbonating, i.e., the compound has a complex impact on macromolecules (Usatov et al., 2005). Thus, further research aimed at studying mechanisms of the chemical effect of hexachlorobenzene on DNA molecule and enzymes of the repair system will help identify the potential level of xenobiotic mutagenic activity on the level of point mutations and predict distant genetic consequences of its impact in the series of organisms of the generations-to-come.

\section{Conclusions}

Chemical soil contamination of the toxic waste ground and dumps of Dombrovskyi potash ore mine near Kalush city leads to high mutagenic activity, which, by the induction level of cytogenetic anomalies in winter wheat root meristem, exceeds the control indicators by 1.8 3.8 times and is equal to mutagenic activity of $\mathrm{N}$-nitrozo-N-methylurea in moderate concentrations. Hexachlorobenzene contamination of the soil of a recultivated area of the toxic waste ground results in the increase of aberrant cell frequency by $2.6-3$ times, and it continues to be a threat to the genome of living organisms. Hexachlorobenzene contamination of the soil together with natural mineral compounds of miningchemical raw materials, even in low concentrations, ensures high mutagenic activity. The spectrum of chromosome aberrations which contained acentric fragments that are typical for chemical mutagenesis expanded in the form of bridge induction, ring chromosomes and micronuclei. A considerable increase of the share of the cells with dicentric chromosomes in the spectrum of the types of chromosome disorders caused by the effect of hexachlorobenzene contamination of the soil of the toxic waste ground can confirm the radiomimetic properties of the chemical genotoxicant. The increase in the number of cells with multiple aberrations, induced by the effect of hexachlorobenzene contamination of the soil within the area of the studied objects, points to the high genotoxicity of the chemical compound and the threat it poses of serious genetic consequences if it penetrates into the environment.

\section{References}

Al-Naber, H. M. F., Slenzak, A., Stranadko, N., Tykhyy, V., Sulukhia, T., Lvovsky, K., Fan, Q., \& Ahmed, K. (2016). Ukraine country environmental analysis. The World Bank, Washington.

Altwaty, N. H., El-Sayed, O. E., Aly, N. A. H., Baeshen, M. N., \& Baeshen, N. A. (2016). Molecular and cytogenetic assessment of Dipterygium glaucum genotoxicity. Anais da Academia Brasileira de Ciências, 88(1), 623-634.

Ang, J., Song, L. Yu., D’Souza, S., Hong, I. L., Luhar, R., Yung, M., \& Miller, J. H. (2016). Mutagen synergy: Hypermutability generated by specific pairs of base analogs. Journal of Bacteriology, 198(20), 2776-2783.

Aoki, Y. (2017). Evaluation of in vivo mutagenesis for assessing the health risk of air pollutants. Genes and Environment, 39, 1-12.

Babatunde, B., \& Anabuike, F. (2015). In vivo cytogenotoxicity of electronic waste leachate from Iloabuchi electronic market, Diobu, Rivers state, Nigeria on Allium cepa. Challenges, 6, 173-187.

Bekker, A. A., \& Agaev, T. B. (1989). Ohrana i control' zagrjaznenija prirodnoj sredy [Protection and control of environmental pollution]. Gidrometeoizdat, Leningrad (in Russian).

Budinsky, R., Gollapudi, B., Albertini, R. J., Valentine, R., Stavanja, M., Teeguarden, J., Fensterheim, R., Rick, D., Lardie, T., McFadden, L., Green, A., \& Recio, L. (2013). Nonlinear responses for chromosome and gene level effects induced by vinyl acetate monomer and its metabolite, acetaldehyde in TK6 cells. Environmental and Molecular Mutagenesis, 54(9), 691-768.

Bulathsinghala, A. T., \& Shaw, I. C. (2013). The toxic chemistry of methyl bromide. Human and Experimental Toxicology, 33(1), 81-91.

Chan, Y. A., Hieter, P., \& Stirling, P. C. (2014). Mechanisms of genome instability induced by RNA-processing defects. Trends in Genetics, 30(6), 245-253.

Chen, Y., Ebenstein, A., Greenstone, M., \& Li, H. (2013). Evidence on the impact of sustained exposure to air pollution on life expectancy from China's Huai River policy. Proceedings of the National Academy of Sciences of the United States of America, 110(32), 12936-12941.

Correia, A. W., Pope, C. A., Dockery, D. W., Wang, Y., Ezzati, M., \& Dominici, F. (2013). The effect of air pollution control on life expectancy in the United States: An analysis of 545 US counties for the period 2000 to 2007. Epidemiology, 24(1), 23-31.

David, R., Ebbels, T., \& Gooderham, N. (2016). Synergistic and antagonistic mutation responses of human MCL-5 cells to mixtures of benzo[a]pyrene and 2-amino-1-methyl-6-phenylimidazo[4,5-b]pyridine: Dose-related variation in the joint effects of common dietary carcinogens. Environmental Health Perspectives, 124(1), 88-96.

Dent, D., \& Dmytruk, Y. (Eds.). (2017). Soil science working for a living. Springer Nature.

Doorn, G. S. (2014). Patterns and mechanisms of evolutionary transitions between genetic sex-determining systems. Cold Spring Harbor Perspectives in Biology, $6(8), 1-17$.

Febbraio, F. (2017). Biochemical strategies for the detection and detoxification of toxic chemicals in the environment. World Journal of Biolgical Chemistry, 8(1), 13-20.

Firbas, P., \& Amon, T. (2014). Chromosome damage studies in the onion plant Allium cepa L. Caryologia, 67(1), 25-35.

Gervais, C., \& Roze, D. (2017). Mutation rate evolution in partially selfing and partially asexual organisms. Genetics, 207(4), 1561-1575.

Guilherme, R. S., Meloni, V. F. A., Kim, C. A., Pellegrino, R., Takeno, S. S., Spinner, N. B., Conlin, L. K., Christofolini, D. M., Kulikowski, L. D., \& Melaragno, M. I. (2011). Mechanisms of ring chromosome formation, ring instability and clinical consequences. BMC Medical Genetics, 12(1), 1-7.

Guo, X., Bian, P., Liang, J., Wang, Y., Li, L., Wang, J., Yuan, H., Chen, S., Xu, A., \& Wu, L. (2014). Synergistic effects induced by a low dose of diesel particulate 
extract and ultraviolet-A in Caenorhabditis elegans: DNA damage-triggered germ cell apoptosis. Chemical Research in Toxicology, 27(6), 990-1001.

Gupta, A. K., Singh, S. P., Singh, M., \& Marboh, E. S. (2018). Mutagenic effectiveness and efficiency of gamma rays and EMS on cape gooseberry (Physalis peruviana L.). International Journal of Current Microbiology and Applied Sciences, 7(2), 3254-3260.

Haidin, A. M., Diakiv, V. O., \& Chikova, I. V. (2014). Kalush - programa revitalizacii' [Kalush - revitalization program]. Technogenic and Ecological Safety, 10(2), 102-107 (in Ukrainian)

Henn, B. M., Botigue, L. R., Bustamante, C. D., Clark, A. G., \& Gravel, S. (2015). Estimating the mutation load in human genomes. Nature Reviews Genetics, $16,333-343$.

Jejges, N. S. (2013). Istoricheskaja rol' Iosifa Abramovicha Rapoporta v genetike. Prodolzhenie issledovanij s ispol'zovaniem metoda himicheskogo mutageneza [The historical role of Joseph Abramovich Rapoport in genetics. Continuation of studies using the method of chemical mutagenesis]. Vavilov Journal of Genetics and Selection, 17(1), 162-172 (in Russian).

Kayalvizhi, K., Kannan, M., \& Ganga, M. (2017). Effect of physical and chemical mutagens on morphological characters in M1V2 generation of tuberose (Polianthes tuberosa L.). International Journal of Current Microbiology and Applied Sciences, 6(4), 2492-2499.

Kumar, G., \& Pandey, A. (2015). Heavy metal induced genomic distortion in root meristems of coriander (Coriandrum sativum L.). International Journal of Research Plant Sciences, 4(5), 47-53.

Kumar, G., \& Srivastava, A. (2015). Clastogenic and mito-inhibitory effect of heavy metals in root meristems of Vicia faba. Chromosome Botany, 10(1), 23-29.

La Croix, R. A., Palsson, B. O., \& Feist, A. M. (2017). A model for designing adaptive laboratory evolution experiments. Applied and Environmental Microbiology, 83(8), 1-14.

Laskar, R. A., \& Khan, S. (2017). Mutagenic effectiveness and efficiency of gamma rays and $\mathrm{HZ}$ with phenotyping of induced mutations in lentil cultivars. International Letters of Natural Sciences, 64, 17-31.

Lysychenko, G., Weber, R., Kovach, V., Gertsiuk, M., Watson, A., \& Krasnova, I. (2015). Threats to water resources from hexachlorobenzene waste at Kalush City (Ukraine) - a review of the risks and the remediation options. Environmental Science and Pollution Research, 22(19), 14391-14404.

M'kacher, R., Maalouf, E. E., Terzoudi, G., Ricoul, M., Heidingsfelder, L., Karachristou, I., Laplagne, E., Hempel, W. M., Colicchio, B., Dieterlen, A., Pantelias, G., \& Sabatier, L. (2015). Detection and automated scoring of dicentric chromosomes in nonstimulated lymphocyte prematurely condensed chromosomes after telomere and centromere staining. International Journal of Radiation Oncology, Biology, Physics, 91(3), 640-649.

Marković, S. Z., Nikolić, L. I., Hamidović, J. L., Grubor, M. G., Grubor, M. M., \& Kastratović, D. A. (2017). Chromosomes aberations and enviromental factors. Hospital Pharmacology, 4(1), 486-490.

Mohapatra, T., Robin, S., Sarla, N., Sheshashayee, M., Singh, A. K., Singh, K., Singh, N. K., Mithra, S. V. A., \& Sharma, R. P. (2014). EMS induced mutants of upland rice variety Nagina22: Generation and characterization. Proceedings of the Indian National Science Academy, 80(1), 163-172.

Oladosua, Y., Rafii, M. Y., Abdullaha, N., Hussind, G., Ramlie, A., Rahimf, H. A., Miaha, G., \& Usmana, M. (2016). Principle and application of plant mutagenesis in crop improvement: A review. Biotechnology and Biotechnological Equipment, 30(1), 1-16.

Parpan, V. I., Shumska, N. V., Rudeichuk-Kobzeva, M. J., \& Mylenka, M. M. (2016). Syntaxonomy of vegetation of Kalush hexachlorobenzene toxic waste landfill (Ivano-Frankivsk region). Biosystems Diversity, 24(2), 364-370.

Pausheva, Z. P. (1988). Praktikum po citologii rastenij [Workshop on plant cytology]. Agropromizdat, Moscow (in Russian).

Rozhko, M. M., Bilec'ka, E. M., Shmatkov, G. G., Erstenjuk, G. M., Kryzhanivs'ka, A. I., Onyshchenko, S. V., Rud'ko, G. I., Samojlik, M. S., Semchuk, J. M., \& Solovjov, V. V. (2014). Rozrobka ta vprovadzhennja systemy zmenshennja tehnogennogo navantazhennja na terytorii' i naselennja ekologichno kryzovyh terytorij [Development and implementation of a system for reducing the man-caused load on the territory and population of ecologically crisis areas]. Ecology and Nature Management, 18, 97-110 (in Ukrainian).

Ryu, T. H., Kim, J.-H., \& Kim, J. K. (2016). Chromosomal aberrations in human peripheral blood lymphocytes after exposure to ionizing radiation. Genome Integrity, 7(1), 1-5.

Sirohi, S., Mago, P., Gunwal, I., \& Singh, L. (2014). Genetic pollution and biodiversity. International Journal of Recent Scientific Research, 5(6), 1152-1155.

Song, L, Y, D'Souza, S, Lam, K, Kang, T. M., Yeh, P. \& Miller, J. H. (2016). Exploring synergy between classic mutagens and antibiotics to examine mechanisms of synergy and antibiotic action. Antimicrobial Agents and Chemotherapy, 60(3), 1515-1520.

Syaifudin, M., Lusiyanti, Y., Purnami, S., Lee, Y. S., \& Kang, C. M. (2017). Assessment of ionizing radiation induced dicentric chromosome and micronuclei in human peripheral blood lymphocytes for preliminary reconstruction of cytogenetic biodosimetry. Atom Indonesia, 43(1), 47-54.

Usatov, A. V., Mashkina, E. V., \& Gus'kov, E. P. (2005). Vlijanie okislitel'nogo stressa na mutagenez u podsolnechnika Helianthus annuus L., inducirovannyj nitrozometilmochevinoj [Influence of oxidative stress on sunflower Helianthus annuus L. mutagenesis induced by nitrosomethylurea]. Genetics, 42(1), 63-70 (in Russian).

Venken, K. J. T., \& Bellen, H. J. (2014). Chemical mutagens, transposons, and transgenes to interrogate gene function in Drosophila melanogaster. Methods, 68(1), 15-28.

Yahaya, T., Obaroh, I., \& Oladele, E. O. (2017). The roles of environmental pollutants in the pathogenesis and prevalence of diabetes: A review. Journal of Applied Science and Environmental Management, 21(1), 5-8.

Yakymchuk, R. A., \& Valyuk, V. F. (2018). Soil mutagenic activity in hazardous waste site of Kalush City (Western Ukraine). Ukrainian Journal of Ecology, $8(1), 880-886$

Zuccarello, D., Dallapiccola, B., Novelli, A., \& Foresta, C. (2010). Azoospermia in a man with a constitutional ring 22 chromosome. European Journal of Medical Genetics, 53(6), 389-391. 